fields. They constitute in turn a challenge to the 'intelligent layman' to fulfil his part of the task. The author's efforts should not be in vain, as the book will provide those with a reasonable grounding in the physical sciences with a straightforward but uniquely comprehensive picture of perhaps the most important field of scientific activity and engineering of the present day. It is refreshing to find a book which shows no tendency to the somewhat hysterical approach to the subject evident in the works of others who aim at catching the attention of the layman. The phase in which there was any justification for such treatment is long past, and a sober factual exposition is now required. The book provides this admirably.

S. C. Curran

\section{BIOLOGY AND MEDICINE OF ATOMIC WARFARE}

Medical Effects of the Atomic Bomb in Japan

Edited by Prof. Ashley W. Oughterson and Prof. Shields Warren. (National Nuclear Energy Series: Manhattan Project Technical Section. Division 8, Vol. 8.) Pp. xvi +477. (London: MeGraw-Hill Publishing Company, Ltd., 1956.) $60 s$.

$\mathrm{M}$

ILITARY science is advancing apace, and not least in the development of atomic weapons. Military medicine must necessarily keep abreast of the times. It is now more than ten years since the first atomic bombs were detonated over Hiroshima and Nagasaki to conclude the Second World War. These nominal atomic bombs were then about a thousand times more powerful than the current high-explosive bombs. 'To-day, 'hydrogen' bombs are rated at about one thousand times the power of nominal atomic weapons. This volume, therefore, late though it may appear to be, is a necessary work of reference for everyone in the medical branches of armed forces and civil defence.

The contents have been hitherto available only in a multitude of specialized reports, such as those of the Joint Commission for the Investigation of the Effects of the Atomic Bomb in Japan and its successor, the Atomic Bomb Casualty Commission. This book summarizes the early reports and supplies much of the evidence in a convenient form. Prof. Ashley Oughterson, clinical professor of surgery in the Yale University School of Medicine, was editor-in-chief of the report (in six volumes) of the Joint Commission. Prof. Shields Warren, professor of pathology in the Harvard Medical School, and lately head of the Division of Biology and Medicine of the Atomic Energy Commission, has personally assessed the pathological material.

There are two main features to be stressed. First, "Although the atomic bomb is a finite weapon whose effects can be calculated and partly offset, it has made possible the infliction of stunning casualties at a far lower cost in men, money and materials than ever before". The medical problems raised are therefore not so much technical as administrativenamely, how to cope with tens of thousands of casualties, as at Hiroshima, with virtually all local facilities destroyed. The element of surprise found the Japanese medical administration wanting; but "seventy per cent of the total deaths, in Hiroshima occurred on the first day. At least another 5 to 10 per cent of those who died were so seriously injured that death was unavoidable. ... It is apparent that if the mortality from atomic bomb explosions is to be effectively reduced, chief reliance must be placed on preventative measures". The second point is that casualties from the secondary effects of blast and from burns presented few novel pathological features. The influence of ionizing radiation on the response to injury was a strikingly new feature, and radiation injury alone was a common cause of death and severe illness. The clinical and pathological features of this syndrome are carefully analysed.

The book is notable for the very large amount of material presented graphically, tabulated or pictorially. There are so many photographs of clinical and histological material that special plates are a rarity, and most of the production is on the very good paper of the ordinary pages. For most of the clinical photographs this is adequate, but many of the photomicrographs are more than usually obscure.

\section{J. F. Loutit}

\section{BUILDING: MYTHS AND MAGIC}

Architecture, Nature and Magic

By W. R. Lethaby. With a Biographical Note by Alfred Powell. Pp. $155+15$ plates. (London: Gerald Duckworth and Co., Ltd., 1956.) 16s. net.

T T was more than fifty years ago when Mr. W. R. Lethaby, who died in 1931, published a little book with the title of "Architecture, Mysticism and Myth". It was true, as the author rather humorously admitted, that there was very little about mysticism in the book; but the title had some substance in it, since it was the first-fruits of a study of what the author considered to be the less understood causes which were so closely connected with the art of building.

Mr. Lethaby believed that ideas of building and architecture generally were intimately allied with other ideas relating to the general structure of the world, and also that man's concept of Nature and his belief in magical properties had a profound influence on the development of ancient architecture. To Mr. Lethaby, man was primarily a builder, and in his architecture he formed a kind of framework for his explanation of the universe. Thus in viewing man's building processes a mere æsthetic appreciation was not enough : it was only by understanding the religious and magical ideas of any particular epoch that the architecture of the period could be fully understood. After "Architecture, Mysticism and Myth" was published, Mr. Lethaby set to work to re-write his thesis in a more comprehensive form. $\mathrm{He}$ found, however, that the mass of material on the early history of man, his myths, his magic and his cults, was so voluminous that he finally gave up the attempt; and it was not until 1928 that he re-wrote, with additions, much of his former material and published it in a series of articles in The Builder under the title "Architecture, Nature and Magic". These are the articles which are now reprinted in the present more convenient form and they illustrate not only the wide range of Mr. Lethaby's reading but also the power of his imagination and the depth of his understanding.

In the course of his discussion, the author deals with man's idea of the fabric of the world, with special reference to the world tree and the temple of 